\section{Fatma Pelin Cengiz}

Kars Devlet Hastanesi, Dermatoloji Kliniği, Kars, Türkiye

Yazışma Adresi/ Correspondence:

Fatma Pelin Cengiz, Kars Devlet Hastanesi, Dermatoloji Kliniği, Kars, Türkiye E-posta: fpelinozgen@hotmail.com Geliş Tarihi/Submitted: 21.10.2013 Kabul Tarihi/Accepted: 17.03.2014

@Telif Hakkı 2014 Türk Dermatoloji Derneği Makale metnine www. turkdermatolojidergisi.com web sayfasından ulaşılabilir.

@Copyright 2014 by Turkish Society of Dermatology - Available on-line at www.turkdermatolojidergisi.com

\title{
Yeni Tanımlanmış Bir T Hücre Alt Tipi: Th22 ve Cilt Hastalıkları
}

A Newly Identified T Cell Subtype: Th22 and Skin Diseases

\section{Özeł}

Th22 hücreleri son dönemlerde tanımlanmış bir CD4 T lenfosit alt tipidir. Naif T lenfositleri ürettikleri sitokinlere göre Th1, Th2, Th9, Th17 ve Th22 hücrelerine dönüşür. İnterlökin 10 (IIL10) ailesinin bir üyesi olan interlökin 22 (İL-22), insanlarda Th17, Th22 ve doğal öldürücü hücreler tarafından üretilmektedir. İL-22 reseptör kompleksi, İL-22 reseptör tip 1 ve İ-10 reseptör 2 alt birimlerinden oluşmaktadır ve genellikle hematopoetik olmayan hücrelerin yüzeyinde bulunur. İL-22 deride keratinosit proliferasyonuna ve epidermal hiperplaziye neden olur. Ayrıca dokunun yeniden yapılanmasında gerekli olan kemokinlerin ve antimikrobiyal peptidlerin salgılanmasını sağlar. Başlangıçta, IL-22'nin Th17 hücreleri tarafından salgılandığı düşünülmekteydi, ancak son zamanlarda İL-22' nin büyük kısmının Th22 hücreleri olarak yeni tanımlanmış bir T hücre tipi tarafından salgılandığı anlaşıımıştır. Th22 hücreleri, Th17 hücrelerinden farklı olarak IL-17 ve interferon- $y$ (IFN-Y) salgılamazlar. Th22 hücreleri, CCR4 ve CCR10 reseptörleriyle normal cilde yerleşirler, ayrıca birçok dermatolojik hastalıkta sayıları artar. Bu yazıda yeni tanımlanmış bir T hücre alt tipi olan Th22 hücrelerinin deri hastalıklarındaki önemini tartışmayı amaçladık.

Anahtar kelimeler: Th22, dermatoloji, immünoloji

\section{Abstract}

Th22 cells are recently identified subtype of CD4 T lymphocytes. Naive CD4 T lymphocytes convert to Th1, Th2, Th9, Th17 and Th22 cells according to the cytokines they product. IL-22, a member of IL-10 family, is produced by natural killer (NK), Th17 and Th22 cells. IL-22 receptor complex is composed of IL-22 receptor 1 (IL-22R I) and IL-10 receptor 2 (IL-10R2) units and IL-22 receptor complex is usually expressed on the surfaces of nonhematopoietic cells. IL-22 induces keratinocyte proliferation and epidermal hyperplasia in the skin. IL-22 promotes the production of antimicrobial peptides and chemokines essential for tissue remodeling. IL-22 was initially thought to be released from Th17 cells however it was recently understood that the major part of IL-22 is released from newly identified subtype of T cell as Th22 cells. Th22 cells don't secrete IL-17 and interferon-Y (iFN-Y), unlike Th 17. Th22 cells are located to the skin by chemokine receptors CCR4 and CCR 10 and their amount is increased in many skin diseases. In this review, we aim to discuss the role of newly identified subtype of T cells, Th22 cells in skin diseases.

Key words: Th22, dermatology, immunology

\section{Giriş}

T lenfositler, B lenfositlerle birlikte edinsel immünitenin hücresel olan komponentlerini oluşturur. Kemik iliğinden köken alan $T$ lenfositler, timusta olgunlaşır ve kan dolaşımına geçer. Dolaşımda bulunan lenfositlerin \%60-\%80 kadarını T hücreleri oluşturur; bunların üçte ikisi CD4, üçte biri CD8 yüzey belirteçlerini taşır. Naif CD4 T hücreleri, salgıladıkları sitokinlere göre farklı alt gruplara ayrılır. Bunlar Th1, Th2, Th9, Th17 ve Th22 hücreleridir. Bu alt grupların farklı özellikleri vardır. Th1 aracılı immün yanıt, hücre içi mikroorganizmalara karşı fagosit aracılı savunmada yer alır. Th2 aracılı immün yanıt ise, helmintik enfeksiyonlara karşı, IgE ve eozinofil-mast hücresi aracılı immün yanıtı güçlendirir. Son yıllarda araştırmacılar, farklı sitokinler salgılayan yardımcı T hücrelerini tanımlamıştır. 2009 yılında, bol miktarda IL-22 salgılayan, Th17 hücrelerinden farklı 
tipte bir CD4 T hücre alt tipi Trifari ve arkadaşları tarafından tanımlanmıştır (1). Bu hücreler, Th22 hücreleri olarak adlandırılmıştır. İL-22'nin kaynağının bu T hücre tipi ve Th17 olduğu anlaşılmıştır. Th22 hücrelerinin cilde yerleşen CCR4, CCR10 reseptörleriyle birlikte CCR10 reseptörlerini yüzeyinde eksprese ettikleri belirtilmiştir (1). Bu tanımlamadan sonra Th22 hücreleriyle ilgili yapılan çalışmaların sayısı artmıştır. Th22 klonlarının, IL-22'yi 6 saatte salgılamaya başladığı, 12 saatte pik yaptığı ve 48 saat boyunca bu düzeyde kaldığı gösterilmiştir (2). Th22 hücreleri, naif T hücrelerinden IL-6 ve TNF- $a$ varlığında meydana gelirler (3). Bunun sonucunda, Th22 hücreleri IL-22 salgılar (Resim 1).

İnterlökin 22 (iL-22), interlökin 10 (iL-10) ailesinin üyelerinden olan bir sitokindir. İL-22 reseptör kompleksi özellikle epitelyal hücrelerde olmak üzere, pankreasta, barsak dokusunda, karaciğerde bulunmaktadır (4-6).

Th22 hücrelerinin keşfiyle birlikte IL-22'nin büyük miktarda Th22 hücreleri tarafından salgılandığı anlaşılmıştır. Th17 ve Th22 hücreleri arasında belirli farklar vardır. Bunlar:

a) Th22 hücreleri, Th17 hücrelerinden farklı olarak sadece IL22 salgılamaktadır. Th17 hücreleriyse IL-22'nin dışında İL-17, IL-4, IFN- $\gamma$ salgılamaktadır $(1,3)$.

b) Th17 hücrelerinin farklılaşması retinoid-related orphan $C$ reseptörü üzerinden olurken, Th22 hücrelerinin farklılaşması aril hidrokarbon reseptörü üzerinden olmaktadır $(3,7)$.

c) Aril hidrokarbon reseptörünün uyarılması IL-22 salgılanmasını uyarırken, IL-17 salgılanmasını inhibe eder (7).

d) Th17 hücrelerinden farklı olarak CCL20 eksprese etmezler (8).

Th22 hücreleri; CD3, CD4 belirteçlerini yüzeylerinde eksprese ederler, doğal öldürücü hücrelerin ve CD8 hücrelerin belirteçlerini eksprese etmezler. Th22 hücreleri ayrıca CCR4, CCR6 ve CCR10 reseptörlerini üzerinde taşır.

Th22 hücreleri, CCR4 ve CCR10 reseptörleriyle cilde yerleşirler, normal deride bulunmalarının yanı sıra çeşitli deri hastalıklarında da miktarlarının arttığı saptanmıştır $(2,9)$. Deride epidermal kompartmanda yüksek oranda bulunduğu görülmüştür (2). Ayrıca IL-22; deride S100A7, S100A8, S100A9,

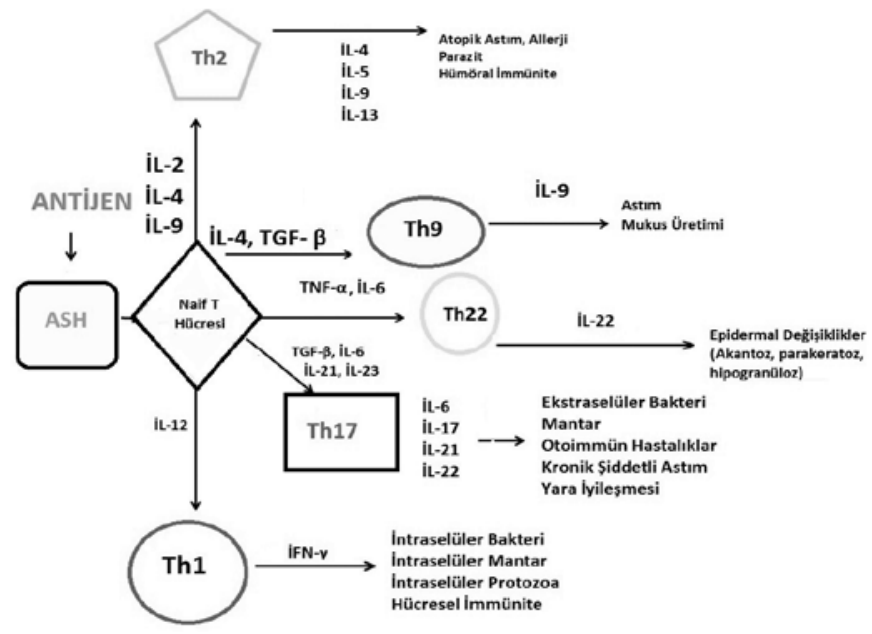

Resim 1. Naif T hücresinin sitokinlerin etkisiyle Th1, Th2, Th9, Th17 ve Th22 hücrelerine dönüşümü $\beta$-defensin-2, ve $\beta$-defensin-3 gibi antimikrobiyal peptidlerin miktarını arttırır (4).

İL-22'nin öneminin araştırıldığı ilk dermatolojik hastalık psoriasistir. Psoriasis, histopatolojisinde epidermal hiperproliferasyon, parakeratoz ve dermiste damarlanma artışıyla karakterizedir. Psoriasisli hastalarda, kontrol grubuna göre serumda İL-22'nin arttığı görülmüştür $(10,11)$, ayrıca psoriasis hastalık şiddeti skorlamasıyla serumda dolaşan IL-22 miktarının korelasyon gösterdiği saptanmıştır (11). Psoriasise yönelik tedavi verilince, psoriasis lezyonlarında artmış miktarda saptanan Th22 hücrelerinin miktarının azaldığı görülmüştür (11). Psoriasisli hastalarda, Th22'nin dışında, Th1 ve Th17 hücrelerinin de arttığı saptanmıştır (12).

Guttat psoriasisle, streptokok enfeksiyonları arasındaki ilişki bilinmektedir. Ferran ve arkadaşları, streptokok enfeksiyonun IL-17 ve IFN- $\gamma$ ile IL-22 salgılanmasını tetiklediğini saptamıştır (13). Ayrica hayvan modellerinde, İL-22'nin in vitro olarak epidermal hiperplaziyle birlikte, hipogranüloza ve parakeratoza neden olduğu gösterilmiştir $(9,14,15,16)$. TNF-a ve İL-6, Th22 hücrelerinin farklılaşmasında önemli olan sitokinlerdir ve bu sitokinlerin de salgılanması psoriasisli hastalarda artmıştır (3).

Behçet hastalığı genellikle genç erişkinlerde başlayan, tekrarlayan oral ve genital ülserler, üveit ve deri bulgularıyla karakterizedir. Behçet hastalığında aktif üveiti olan hastalarda oküler örnekler alınmış ve bu örneklerde yüksek miktarda İL-22 ve TNF-a olduğu saptanmış, ancak Th1 sitokini IFN- $\gamma$ ve Th17 sitokini IL-17 normal olarak bulunmuş. Hastaların periferik kan örneklerinde ise in vitro olarak IL-6 ve TNF-a varlığında CD4 T hücrelerinin Th22 hücrelerine dönüştüğü görülmüş (17). Bu çalışmanın sonuçlarına göre, İL-22 ve TNF-a'nın Behçet hastalarında oküler immün cevapta bu sitokinlerin önemli rolü olduğu düşünülmüştür.

Atopik dermatit, genellikle bebeklik döneminde başlayan, infant ve çocukluk döneminde devam edebilen ekzematöz bir hastalıktır. Cildin bariyer fonksiyonu bozulmuştur, involukrin, filaggrin ve lorikrin miktarı azalmıştır. Akut fazda hastalık Th2 yolağındayken, kronik fazda Th1 yolağına doğru kayar. Nograles ve arkadaşları, atopik dermatitin kronik lezyonlarında, psöriazis lezyonlarından daha yüksek oranda İ-22'nin eksprese olduğunu göstermiştir (18). Atopik dermatitte, IL-22'nin büyük kısmının Th22 hücreleri tarafından üretildiği görülmüştür. Szegedi ve arkadaşları kronik atopik dermatit lezyonlarında Th17 hücreleri azalırken, Th22 hücrelerinin arttığını göstermiştir (19). Yapılan çalışmalarda atopik dermatit lezyonlarındaki Th22 hücrelerinin artışıyla uyumlu olarak, serum İL-22 miktarının da arttığı gösterilmiştir $(20,21)$. Ayrıca, serumda atopik dermatitin şiddetini gösteren bir belirteç olan CCL17 ile serum IL-22 düzeylerinin korelasyon gösterdiği saptanmıştır (20). Th22 hücrelerinde eksprese olan CCR4'ün ligandı olan Th2 hücrelerinin üzerinde eksprese olan CCL17'nin atopik dermatit lezyonlarında arttığı gösterilmiştir ve bu kemokin sayesinde Th2 hücrelerin atopik dermatit lezyonlarında biriktiği düşünülmektedir (22). CCR10 ligandı olan CCL27'nin de atopik dermatit lezyonlarında arttığı gösterilmiş̧ir $(23,24)$. Bunların sonucu olarak, atopik dermatitli derilerde artmış CCL17 ve CCL27'nin, Th22 birikimine neden olduğu düşünülmektedir. 
İn vitro yapılan çalışmalarda, kültürü yapılmış keratinositlerde İL-22'nin filagrin, lorikrin ve involukrin ekspresyonunu azalttığı görülmüştür $(9,14)$. Yapılan bir çalışmada, dbUVB tedavisinin kronik atopik dermatitte deride IL-22 ekspresyonunu azalttığı, bunun sonucunda epidermal hiperplazinin azaldığı görülmüştür (25). Ayrıca UVB tedavisi sırasında filagrin ekspresyonunun normale dönmesinin yanısıra histolojik ve klinik iyileşmeyle korele olarak S100A7, S100A8 ve antimikrobiyal peptidlerin miktarının azaldığı görülmüştür.

Kontakt dermatit çeşitli antijenlere ve irritanlara maruziyetin neden olduğu yaygın bir enflamatuar dermatittir. Psöriazis ve atopik dermatitte olduğu gibi, allerjik kontakt dermatitte de lezyoner deride IL-22 üreten T hücrelerinin sayıca arttığı gösterilmiştir (2). Ayrıca deride IL-22 eksprese eden hücrelerin sayısı artmıştır. Nikel alerjisi olan hastalara yama testi yapıldıktan sonra serumlarında kontrol grubuna göre IL22 'nin yüksek olduğu görülmüştür (26).

Skleroderma fibrozis ile karakterize, deri ve iç organ tutulumu yapabilen otoimmün bir bağ doku hastalığıdır. Birçok otoimmün hastalık Th1 aracılı patolojiye sahipken, sistemik sklerodermanın patofizyolojisi Th2 aracılıdır. Yakın zamanda, Truchetet ve arkadaşları sistemik sklerodermalı hastaların dolaşımında Th2 ve Th17 hücrelerinin yanı sıra Th22 hücrelerinin de arttığını göstermiştir (27). Deride IL17 yükselmemesine rağmen IL-22'nin arttığı gösterilmiştir (28). Ayrıca normalde yara iyileşme bölgesine sınırlı olan, IL22 'nin indüklediği keratin 6 ve 16'nın sistemik sklerodermalı hastaların derisinde yüksek olduğu görülmüştür (29). Cildi infiltre eden Th22 hücrelerinin fibroblast growth faktör ve fibrozis ilişkili kemokin CCL7'yi yüksek oranda eksprese ettikleri için, hastalığın gelişiminde etkili olduğu düşünülmektedir (2).

Kutane $T$ hücreli lenfoma, eozinofili ve $\operatorname{lgE}$ yüksekliğinin eşlik ettiği, Th2 aracılı olan deri lenfomasıdır. Miyagaki ve arkadaşları, kutane $T$ hücreli lenfoması olan hastaların cildinde, IL-17'yü düşük bulmalarına rağmen, IL-22'yi yüksek bulmuştur (30). Serum İL-22 ve CCL20 düzeyleri, hastalık şiddetiyle korele olarak yüksek bulunmuştur. Ayrıca serum IL22 düzeyleri, hastalık şiddetini gösteren LDH, siL-2R, CCL27 ile korele olarak yüksek bulunmuştur .

Zhang ve ark.'nın yaptığı çalışmada, IL-22'nin in vitro olarak skuamöz hücreli karsinom gelişimini hızlandırdığı ve skuamöz hücreli karsinomda İL-22 ekspresyonunun yüksek olduğu görülmüştür (31).

Sekonder sfilizli hastalarda periferal kanlarında Th17 ve Th22 hücrelerinin araştıııldığı bir çalışmada, Th17 ve Th22 hücreleri birbiriyle pozitif korelasyon göstererek, yüksek bulunmuş. Th17 ve Th1 hücreleri arasında ise negatif korelasyon görülmüş. Th22 hücreleri ile IL-6 ve İL-23 düzeyleri arasında pozitif korelasyon olduğu görülmüş (32).

Wolk ve ark.'nın hidradenitis süpürativalı hastalarda yaptığı çalışmada, normal cilde göre hidradenitis süpürativa lezyonlarında İL-22 ve İL-20'yi yüksek bulurken, psoriasis lezyonlarına göre daha düşük bulmuştur. Ayrıca bu çalışmada, hidradenitis süpürativa lezyonlarında IL-22 ve IL-20 ile korele olarak antimikrobiyal proteinler de düşük bulunmuştur. Bu yüzden İL-22 ve İL-20'nin psoriasise göre olan rölatif düşüklüğünün antimikrobiyal peptid düşüklügüne neden olduğu düşünülmüştür. Bu çalışmada Th22 hücrelerinin, Th17 hücrelerine göre daha yüksek miktarda İL-22 üreticisi olduğu düşünülmüştür. Ayrıca bu lezyonlarda, İL-22 düşüklüğünün, İL-20 düşüklüğüne neden olduğu iddia edilmiştir. Dermatolojik hastalıklarda, İL-22 eksikliğinin gösterildiği ilk çalışma olmuştur (33).

Sonuç olarak IL-22 uzun zamandır bilinmektedir ve etkileri birçok hastalıkta araştırılmıştır. Ancak Th22 hücreleri yeni tanımlanan bir T hücre alt tipidir, hastalıklardaki önemi Th17 hücrelerinden ayrılarak saptanmalıdır. Bunun sonucu olarak, birçok cilt hastalığında Th22 hücrelerine yönelik yeni tedavi yöntemleri geliştirilebilecektir.

\section{Kaynaklar}

1. Trifari S, Kaplan CD, Tran EH et al. Identification of a human helper T cell population that has abundant production of interleukin 22 and is distinct from $T(H)-17, T(H) 1$ and $T(H) 2$ cells. Nat Immunol. 2009 Aug;10(8):864-71.

2. Eyerich $\mathrm{S}$, Eyerich $\mathrm{K}$, Pennino $\mathrm{D}$ et al. Th22 cells represent a distinct human T cell subset involved in epidermal immunity and remodeling. J Clin Invest. 2009 Dec;119(12):3573-85.

3. Duhen T, Geiger R, Jarrossay D et al. Production of interleukin 22 but not interleukin 17 by a subset of human skin-homing memory T cells. Nat. Immunol. 2009; 10:857-863.

4. Sonnenberg GF, Fouser LA, Artis D. Border patrol: regulation of immunity, inflammation and tissue homeostasis at barrier surfaces by IL-22. Nat Immunol 2011;12:383-90.

5. Sonnenberg GF, Fouser LA, Artis D. Functional biology of the IL-22-IL-22R pathway in regulating immunity and inflammation at barrier surfaces. Adv Immunol 2010;107:1-29.

6. Zenewicz LA, Flavell RA. Recent advances in IL-22 biology. Int Immunol 2011;23:159-63.

7. Ramirez JM, Brembilla NC, Sorg $\mathrm{O}$ et al. Activation of the aryl hydrocarbon receptor reveals distinct requirements for IL-22 and IL-17 production by human T helper cells. Eur J Immunol 2010;40: 2450-9.

8. Annunziato, F., et al. 2007. Phenotypic and functional features of human Th17 cells. J. Exp. Med. 204:1849-1861.

9. Nograles KE, Zaba LC, Guttman-Yassky E et al. Th17 cytokines interleukin (IL)17 and IL-22 modulate distinct inflammatory and keratinocyte-response pathways. Br J Dermatol 2008;159:1092-102.

10. Boniface K, Guignouard E, Pedretti $\mathrm{N}$ et al. A role for $\mathrm{T}$ cell-derived interleukin 22 in psoriatic skin inflammation. Clin Exp Immunol 2007;150:407-15.

11. Wolk K, Witte E, Wallace $E$ et al. IL-22 regulates the expression of genes responsible for antimicrobial defense, cellular differentiation, and mobility in keratinocytes: a potential role in psoriasis. Eur J Immunol 2006;36:130923.

12. Kagami S, Rizzo HL, Lee JJ et al. Circulating Th17, Th22, and Th1 cells are increased in psoriasis. J Invest Dermatol 2010;130:1373-83.

13. Ferran $M$, Galvan $A B$, Rincon $C$ et al. Streptococcus induces circulating $\mathrm{CLA}(+)$ memory T-cell-dependent epidermal cell activation in psoriasis. J Invest Dermatol 2013;133:999-1007.

14. Boniface K, Bernard FX, Garcia M et al. IL-22 inhibits epidermal differentiation and induces proinflammatory gene expression and migration of human keratinocytes. J Immunol 2005;174:3695-702.

15. Sa SM, Valdez PA, Wu J et al. The effects of IL-20 subfamily cytokines on reconstituted human epidermis suggest potential roles in cutaneous innate defense and pathogenic adaptive immunity in psoriasis. J Immunol 2007;178:2229-40.

16. Wolk K, Haugen HS, Xu W et al. IL-22 and IL- 20 are key mediators of the epidermal alterations in psoriasis while IL-17 and IFN-gamma are not. J Mol Med 2009;87:523-36.

17. Sugita S, Kawazoe $Y$, Imai A et al. Role of IL-22- and TNF-a producing Th22 cells in uveitis patients with Behcet's disease. J Immunol. 2013 Jun 1;190(11):5799-808.

18. Nograles KE, Zaba LC, Shemer A et al. IL-22-producing "T22" T cells account for upregulated IL-22 in atopic dermatitis despite reduced IL-17-producing TH17 T cells. J Allergy Clin Immunol 2009;123:1244-52.

19. Szegedi K, Kremer AE, Kezic S et al. Increased frequencies of IL-31-producing T cells are found in chronic atopic dermatitis skin. Exp Dermatol 2012;21:431-6. 
20. Hayashida S, Uchi H, Takeuchi S et al. Significant correlation of serum IL-22 levels with CCL17 levels in atopic dermatitis. J Dermatol Sci 2011;61:78-9.

21. Kanda N, Watanabe S. Increased serum human beta-defensin-2 levels in atopic dermatitis: relationship to IL-22 and oncostatin M. Immunobiology 2012;217: 436-45.

22. Kakinuma T, Nakamura K, Wakugawa M et al. Thymus and activationregulated chemokine in atopic dermatitis: serum thymus and activationregulated chemokine level is closely related with disease activity. J Allergy Clin Immunol 2001;107:535-41.

23. Homey B, Alenius H, Muller A et al. CCL27-CCR10 interactions regulate T cellmediated skin inflammation. Nat Med 2002;8: 157-65.

24. Kakinuma T, Saeki H, Tsunemi $Y$ et al. Increased serum cutaneous T cellattracting chemokine (CCL27) levels in patients with atopic dermatitis and psoriasis vulgaris. J Allergy Clin Immunol 2003;111: 592-7.

25. Tintle S, Shemer A, Suarez-Farinas $M$ et al. Reversal of atopic dermatitis with narrow-band UVB phototherapy and biomarkers for therapeutic response. $J$ Allergy Clin Immunol 2011;128: 583-93.

26. Ricciardi L, Minciullo PL, Saitta S et al. Increased serum levels of IL-22 in patients with nickel contact dermatitis. Contact Dermatitis 2009;60:57-8.
27. Truchetet $M E$, Brembilla NC, Montanari $E$ et al. Increased frequency of circulating Th22 in addition to Th17 and Th2 lymphocytes in systemic sclerosis: association with interstitial lung disease. Arthritis Res Ther 2011;13. R166.

28. Mathian A, Parizot C, Dorgham K et al. Activated and resting regulatory $T$ cell exhaustion concurs with high levels of interleukin-22 expression in systemic sclerosis lesions. Ann Rheum Dis 2012;71:1227-34.

29. Aden N, Nuttall A, Shiwen X et al. Epithelial cells promote fibroblast activation via IL-1alpha in systemic sclerosis. J Invest Dermatol 2010;130:2191-200.

30. MiyagakiT, Sugaya M, Suga Het al. IL-22, but not IL-17, dominant environment in cutaneous T-cell lymphoma. Clin Cancer Res 2011;17:7529-38.

31. Zhang S, Fujita H, Mitsui H et al. Increased Tc22 and Treg/CD8 ratio contribute to aggressive growth of transplant associated squamous cell carcinoma. PloS ONE 2013;8:e62154.

32. Zhu A, Han $H$, Zhao $H$ et al. Increased frequencies of Th17 and Th22 cells in the peripheral blood of patients with secondary syphilis. FEMS Immuno Med Microbiol. 2012 Dec;66(3):299-306.

33. Wolk K, Warszawska K, Hoeflich C et al. Deficiency of IL-22 contributes to a chronic inflammatory disease: pathogenetic mechanisms in acne inversa. $J$ Immunol. 2011 Jan 15;186(2):1228-39. 